\title{
Risk in Implementing Building Information Modelling (BIM) in Malaysia Construction Industry: A Review
}

\author{
Ibtisam Azwani Mat Ya'acob ${ }^{1 *}$, and Faizul Azli Mohd Rahim ${ }^{2}$ and Nurshuhada Zainon ${ }^{3}$ \\ ${ }^{1}$ Lee Kong Chian Faculty of Engineering and Science, Universiti Tunku Abdul Rahman, Jalan Sungai \\ Long, Bandar Sungai Long, Cheras, 43000 Kajang, Selangor, Malaysia \\ 1, 2, ${ }^{3}$ Project Management, Procurement \& Economic Research Group, Centre for Building, \\ Construction and Tropical Architecture, Faculty of Built Environment, Universiti Malaya, Jalan \\ Universiti, 50603, Kuala Lumpur, Malaysia
}

\begin{abstract}
Building Information Modelling (BIM) terminology in the construction industry has been widespread used as industry standard buzzword term. BIM could open up a broad range of benefits in the construction industry. However, rate of implementation does not match its benefits. Why BIM has not been fully adopted in construction industry? The underlying problem to the above-mentioned issue were arisen due to the barriers, challenges and risks. These can be a potential factor to jeopardise the successfulness of the construction project by affecting the cost, time and quality. The said factors can be an actual risk which later on bringing construction project to failure. Thus, it crucial to identify the potential risk as a basis for risk assessment and risk response process. Moreover, risk identification relatively important since the risk assessment and risk response process are applied only to the regornised risk factors. Therefore, the aim for this paper is to review the possible risks in implementing BIM in construction industry.
\end{abstract}

\section{Introduction}

Building Information Modeling (BIM) is an emerging digital information technology in a virtual space to achieve high quality and efficient of construction and management $[1,2]$. BIM can be defined as a collaboration of information and simulation in planning, design, construction and facility's operation [3]. It involves with learning new software, reinvent the workflow, training and assigning staff responsibility [4]. Recently, the growing needs of BIM in Architectural, Engineering and Construction (AEC) industry led by a variety of benefit offered to facilitate projects execution. Rely on that, believed BIM can become as a core technology used in the construction industry [5].

BIM's terminology within the context of AEC has been widespread used as industry standard buzzword term since the early 2000s [1]. Malaysia started to implement BIM concept in 2007, initiated by Director of Public Works Department (PWD) with first project

\footnotetext{
*Corresponding author: azwani@utar.edu.my
} 
Multipurpose Hall of Universiti Tun Hussein Onn Malaysia (UTHM), Johore in the Southern region of Malaysia and National Cancer Institute of Malaysia, Putrajaya. Nowadays, BIM implementation in Malaysia is keen to be more suitable for complex projects and high risk projects [2]. However, construction project particularly mega projects have grown in size and quantity are becoming significantly complex and difficult to manage $[6,7]$.

Risk in projects can be defined as the probability of an event occurring that is likely impacted project outcome such as time, cost and quality. It can be measured in terms of likelihood and consequence. Risks vary in nature, severity and consequence, hence there is a high demand for systematic risk management in order to reduce the possibility of these hazards effectively [8]. Failure to manage risks may jeopardized the project outcome by affecting the cost, time and quality of construction projects $[8,9]$. Thus, this research paper reviewed a potential risk related with BIM construction project.

\subsection{Problem Statement}

Researchers that look into trends of a benefit of BIM have increased in the recent year. A long list of tremendous benefits of BIM was identified. BIM could lead to a broad range of changes in the construction industry at almost every level within a building life cycle [4]. The benefit varies along the project life cycle and affected all project team members. In pre-construction stage, BIM can be utilised in planning, design, scheduling, cost estimation and documentation. Meanwhile, during construction stage BIM will support a fabrication, construction and construction logistic process. BIM reach the upmost application level in operation and maintenance during post construction stage.

However, its rate of implementation yet to match its benefits. Even though with long benefit list, a question arises: why BIM has not been fully adopted? Why BIM implementation in Malaysian Construction Industry are considered low? [10]. This slow pace implementation issue kept persisting in Malaysia's scenario [11]. On the broader perspective, The Royal Institution of Chartered Surveyors (2017) stated even though BIM is an increasingly important component in the global built environment, but adoption of BIM in Asia still lags behind. In line with that, Bui, Merschbrock, \& Munkvold concludes that developing countries have to develop new BIM solution to address the challenges and risks in the context of local construction industries [12].

Ghaffarianhoseini et al., stated the problems underlying the low adoption level were arisen due to the scepticism concerning its full feasibility and real risks and challenges [1]. Zakaria et al., also mentioned that Malaysian's construction player are still doubtful with BIM effectiveness because of the limited proven data of successful rate [10]. Recently, many research on the benefits attained by implementing BIM are not in Malaysia and BIM application is limited in the fragmented nature of the Malaysian construction industry. Further study shown the contractor Grade 1 (G1) to Grade 6 (G6) are not ready to implement BIM in Malaysia construction projects due to technical risk namely hard to use information technology (IT) and financial issue to purchase BIM tools such as Revit Architectural, Revit Structural and Navisworks as well as to attend BIM-related training [2].

Several BIM publications have addressed the challenges and potential risk in implementing BIM. Eastman, Teicholz, Sacks, \& Liston described the barriers for BIM implementation are the work process changes and technological risks [13]. Meanwhile, AEC UK provides the BIM protocal (2015) to give a guidance for BIM interoperability problem. A same approach was implemented when Singapore AEC established the Singapore BIM Guide version 2.0 to address the the risk allocation and intellectual property rights in BIM project. In Malaysia, the study was carried out by Construction Research 
Institute of Malaysia (CREAM, CIDB) shown barriers to BIM implementation are identified as technology system risk and technology financial risk from the perspective of individual and organisations [14]. Chien, We \& Huang, mentioned risk management in BIM project is more crucial, more complex which involved a big amount of investment than conventional construction projects [5]. The bigger the size and complexity of the project are, the bigger risk will be aroused [9]. Alreshidi, Mourshed, \& Rezgui pointed out that barriers and issues pertaining to BIM adoption in a collaborative environment would affect the outcome of the construction project if such barriers are still instilled in the project [15].

Being understood that projects are commonly influenced by multiple risk factors regardless of project size or technology used, the said risk factors must be identified and manage systematically during the early risk-management process. Understanding the characteristics of the risk and the severity of risks are important to assess the risk and develop a risk response strategy. Risk can be a potential factor to jeopardise the successfulness of the project by affecting the cost, time and quality. The said factors can be an actual problem which later on bringing construction project to failure. Thus, it crucial to identify the potential risk at the first place as a basis for risk assessment and risk response process. Risk identification relatively important because the process of risk assessment and risk response are applied only to the potential risks that have been identified in earlier stage. Therefore, this study aims to identify the risk in implementing BIM in Malaysia construction industry.

\section{Risk identification}

The concept of risk is adopted in different fields and with a variety of different terms, such as "hazard", "threat", "challenge", or "uncertainty" [8]. Therefore, these terms were combined and considered as key word when conducting the literature review. A systematic risk management in the construction industry consists of three main stages; risk identification, risk asssessment, and risk response. Risk identification is the first stage in risk management process which is to identify the relevant and potential risk associated with the project or organisation. It develops the basis for the next steps. This stage is crucial because the processes of risk assessment and risk response are applied only to the identified risks factors [5]. If risk managers unable to identify all possible losses or challenge in the project or organisation, then these non-identified risks will become non-manageable and jeopardize the successful completion of a project and affecting the project outcomes.

\subsection{Risk identification process}

A systematic literature review is adopted in this paper to identify the potential risk factor on BIM implementation. The purpose of the systematic literature review is to gain overview opinion and standpoint from different authors on the topic of study. To identify risks effectively, many approaches have been suggested in the literature for classifying risks. Pittard and Sell categorized BIM in 3 main components namely; process, people and technology [16]. Chien, Wu and Huang presented a list of BIM risk factors extracted from different nature of project consists of general construction project and IT project [5]. In a nutshell, many ways can be used to classify the risks associated with construction projects generally and BIM project specifically. The rationale for choosing a specific method must cater the purpose of the research. These processes are important because the assessment and response strategy will vary according to the nature of risk classification. 


\subsection{BIM project risk factors}

BIM is keen to be more suitable for complex projects and high risk projects [2]. Relatively, risk will increase when size and complexity of construction projects are increasing [17]. Thus, risk management in BIM project is crucial as BIM project may involve with new challenges and facing new risk factors. Comprehensive information is important in determining risks and understanding the possibility of likelihood and the consequences of each risk. Existing information sources from journal articles, proceedings and conferences, books and online sources need to be accessed and reviewed. Therefore in this paper, various sources have been reviewed comprises of risk in IT and software projects and risk in BIM projects. Risk associated in IT project is considered since the successfulness on BIM implementation are depending on the usage of software tools. The identified risks later on were classified based on previous scholars's categorisation as listed in Table 1. Futhermore, the risk description were summarised under 4 main categories namely; technical risk, management risk, financial risk and legal risk as shown in Table 1.

Table 1. Risk in Implementing BIM

\begin{tabular}{|c|c|c|}
\hline Risk categories & Description & Literature \\
\hline Technology Risk & $\begin{array}{ll} & \text { Interoperability,compatibility complexity } \\
\text { - } & \text { license policies } \\
\text { - } & \text { risk regarding data sharing } \\
\text { - } & \text { version control problem } \\
\text { - } & \text { data loss during BIM-IFC file exchange } \\
\text { - } & \text { insufficient hardware } \\
\text { - } & \text { lack of software compatibility } \\
\text { - } & \text { BIG DATA software unable } \\
\text { - } & \text { upgrading the technology } \\
\text { - } & \text { no proper ICT infrastructure }\end{array}$ & $\begin{array}{c}{[1,5,10,14,17,} \\
18,19]\end{array}$ \\
\hline $\begin{array}{l}\text { Management } \\
\text { Risk }\end{array}$ & 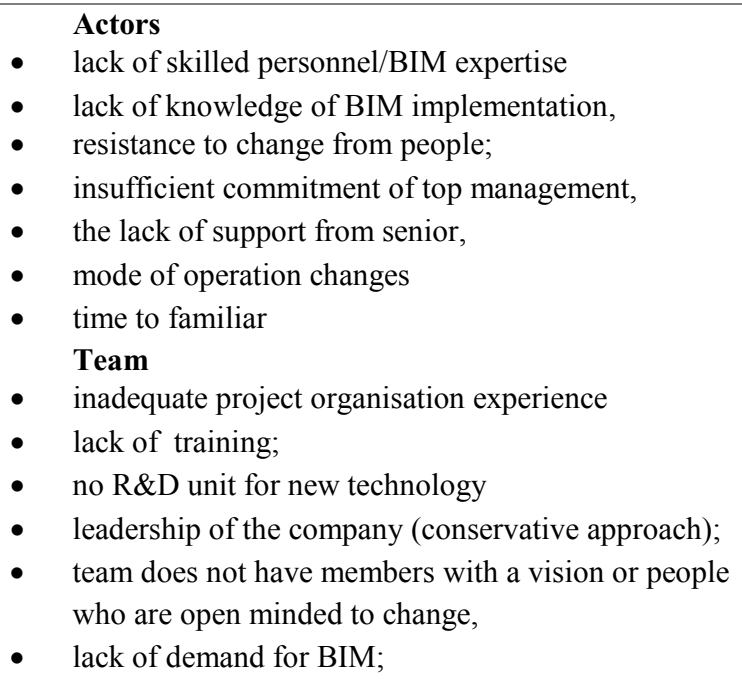 & $\begin{array}{c}{[1,4,5,10,14} \\
15,17,18,19 \\
20,21,22]\end{array}$ \\
\hline Financial Risk & $\begin{array}{l}\text { Financial } \\
\text { - } \quad \text { lack of funds } \\
\text { - } \quad \text { cost challenges } \\
\text { - } \quad \text { investment includes software and hardware and }\end{array}$ & $\begin{array}{c}{[5,14,15,17,18} \\
19,20,21,21,23]\end{array}$ \\
\hline
\end{tabular}




\begin{tabular}{|c|c|c|}
\hline & $\begin{array}{ll} & \text { human resources } \\
\text { - } & \text { high initial investment costs }\end{array}$ & \\
\hline Legal Risk & $\begin{array}{ll}\text { - } & \text { BIM Standard and legal BIM } \\
\text { - } & \text { intellectual property } \\
\text { - } & \text { ownership or licensing issues of data model } \\
\text { - } & \text { unclear policies for re-use BIM model } \\
\text { - } & \text { unclear level of responsibility } \\
\text { - } & \text { liability issue derived from joint authorship of } \\
\text { - } & \text { different BIM model } \\
\text { - } & \text { risk for accuracy of data } \\
\text { - } & \text { no specific BIM protocol } \\
\text { - } & \text { no standard contract for BIM project } \\
\text { - } & \text { dispute-settlement mechanisms risk, } \\
\text { - } & \text { contract obligations in certain countries or unified } \\
\text { - documentation } & \text { company knowledge leaked }\end{array}$ & $\begin{array}{c}{[1,5,14,15,18} \\
19,20,21,23]\end{array}$ \\
\hline
\end{tabular}

\subsubsection{Technology risk}

Technical risks are referring to technical issue pertaining to the implementation of BIM in construction project. The interoperability between application and software compatibility issue are considered a major risk in implementing BIM. This problem arises when a single software tool is developed to accomplish the requirement from different discipline [18, 31]. Different project team are required to use a same BIM model in their practice, resulting the compatibility issue in transferring the data from their existing software to a new BIM software. They also facing the risk of data loss during data transferring process and during the updating a new version. In order to accomplish a full BIM adoption in construction project, good infrastructure support focusing on open file exchange formats, like the industry foundation classes (IFC) should establish especially for developing country like Malaysia to ensure the date model are control by government agency and not the software vendor.

\subsubsection{Management risk}

Management risk can be divided into two broad categories namely actor risk and team risk. Actor risk meant for an individual attribute such as reluctant to change from their comfort zone, lengthy time to familiar with new technology, and lack of BIM experience. These will demotivate the organisation to implement BIM in their project. On the other hand, lack of training and conservative leadership approach will bring a high risk in organisation. The decision maker, should have a clear vision or demand for BIM adoption in their organisation. This attitute will open a new opportunity for the management to provide the training to their subordinate and to establish a Research and Development (R\&D) centre in their organisation. Furthermore, in ensuring BIM being implemented in organisation, only company with adequate BIM knowledge and BIM experience are allowed to tender for BIM project to avoid the probability of project failure. 


\subsubsection{Financial risk}

Cost will be one of the risk in implementing BIM in organisation. It requires a large initial investment in updating software, hardware and provide training to staff [18]. It also costly in terms of changing the work flow and work process. In Malaysia, contractor Grade 1 (G1) to Grade 6 (G6) are still not ready to implement BIM in their construction project due to a large amount of money to purchase the BIM software and to attend the training [2].

\subsubsection{Legal risk}

Absent of national BIM standard in construction industry create a high risk in implementing BIM. There is no clear standard and policy on BIM process and procedure, no legal provision for intellectual property, cyber security, and ownership of the data model. Who is the owner of the data model? Adoption of BIM are initiative by the organisation and yet no mandate from government to fully implement BIM in construction project both in public or private project. Therefore, the organisation use their own standard and modified from other country BIM standard to make suit with Malaysian construction industry. Thus, this standard tend to be a project basis rather than national standard based. Furthermore, there is also no standard contract for BIM project which stipulated the contract obligation among parties involved and dispute settlement mechanism. This will create a big risk in term of unclear level of responsibility among the project team. Who will bear the responsibility if any inaccuracy or mistake detected since all have 'touch up the information' in the same data model?

\section{Conclusion}

Building Information Modeling (BIM) becomes a core technology used in construction industry due to its benefits and positive impacts towards the project objectives. However, the adoption rate is still at very low level and slow pace. The main problem of this issue is concerning real risks and challenges. To succeed in BIM implementation, its important to have a systematic risk management of how risk being mitigates and the challenges being overcome. This paper focusing on the $1^{\text {st }}$ stage of risk management which in risk identification. A summary of risk factors in BIM project were presented and categorised under 4 main categories; technical risk, management risk, financial risk and legal risk. This identified risk serve as initial stage in systematic risk management process. It's crucial to identify the potential risk in order to enable the organisation to evaluate, assess the risk and subsequently propose an effective risk response strategy. Failure to recognised the risk might be affected and jeopardised the project outcome. Risk assessment and risk response strategy for BIM implementation are highly depending on the comprehensive risk factors. Recommended that the list of risk factors can be enhance by combining appropriate techniques from literature review, interview and brainstorming. This research outcome is proposed as an ongoing basis for the development of subsequent stage in risk management process involving risk assessment and risk response strategy.

\section{References}

1. A. Ghaffarianhoseini, J. Tookey, A. Ghaffarianhoseini, N. Naismith, S. Azhar, O. Efimova, K. Raahemifar, Building Information Modelling (BIM) uptake: Clear benefits, understanding its implementation, risks and challenges. Renewable and Sustainable Energy Reviews, (October 2015). 
https://doi.org/10.1016/j.rser.2016.11.083

2. A.A. Latiffi, S. Mohd, N. Kassim, M.S. Fathi, Building Information Modeling ( BIM ) application in Malaysian construction industry. International Journal of Construction Engineering and Management, 2(March 2016), 1-6 (2013). https://doi.org/10.5923/s.ijcem.201309.01

3. R. Takim, M. Harris, A.H. Nawawi, Building Information Modeling (BIM): A new paradigm for quality of life within Architectural, Engineering and Construction (AEC) industry. Procedia - Social and Behavioral Sciences, 101, 23-32 (2013). https://doi.org/10.1016/j.sbspro.2013.07.175

4. Y. Arayici, P. Coates, L. Koskela, M. KAgioglou, C. Usher, K. O'Reilly, Technology adoption in the BIM implementation for lean architectural practice. Automation in Construction, 20(2), 189-195 ( 2011).

https://doi.org/10.1016/j.autcon.2010.09.016

5. K.F.Chien, Z.H. Wu, S.C. Huang, Identifying and assessing critical risk factors for BIM projects: Empirical study. Automation in Construction, 45, 1-15 (2014). https://doi.org/10.1016/j.autcon.2014.04.012

6. D. Bryde, M. Broquestas, J.M. Volm, The project benefits of building information modelling (BIM). International Journal of Project Management, 31(7), 971-980 (2013). https://doi.org/10.1016/j.ijproman.2012.12.001

7. Y. Lu, L. Luo, H. Wang, Y. Le, Q. Shi, Measurement model of project complexity for large-scale projects from task and organization perspective. International Journal of Project Management, 33(3), 610-622 https://doi.org/10.1016/j.ijproman.2014.12.005

(2015).

8. Y. Zou, A. Kiviniemi, A, S.W. Jones, A review of risk management through BIM and BIM-related technologies. Safety Science (2015). https://doi.org/10.1016/j.ssci.2015.12.027

9. E. K, Zavadskas, Z. Turskis, J. Tamosaitiene, Risk Assessment of Construction Projects. Journal of Civil Engineering and Management, 16(1), 33-46 (2010). https://doi.org/10.3846/jcem.2010.03

10. Z. Zakaria, N. Mohamed Ali, A. Tarmizi Haron, a J. Marshall-Ponting, Z. Abd Hamid, Exploring the adoption of Building Information Modelling (BIM) in the Malaysian construction industry: A qualitative approach. IJERT: International Journal of Research in Engineering and Technology, 2(8), 384-395 (2013). https://doi.org/10.1017/CBO9781107415324.004

11. S. Mamter, A. Rashid, A. Aziz, Holistic BIM Adoption and Diffusion in Malaysia. The 4th International Building Control Conference 2016 (IBCC 2016), 66, 1-8 (2016). https://doi.org/10.1051/matecconf/20166600094

12. N. Bui, C. Merschbrock, B.E. Munkvold, A Review of Building Information Modelling for Construction in Developing Countries, Procedia Engineering, 164, 487-494 (2016). https://doi.org/10.1016/j.proeng.2016.11.649

13. C. Eastman, P. Teicholz, R. Sacks, K. Liston, (2011). BIM Handbook: A Guide to Building Information Modeling for Owners, Managers, Designers, Engineers and Contractors. Building (Vol. 2) (2011).

14. M. Harris, A. I. Che Ani, A. Tarmizi Haron, A. H. H., The way forward for Building Information Modelling (BIM) for constructions in Malaysia. Malaysian Construction 
Research Journal (Mcrj), 15(2), 1-9 (2014).

15. E. Alreshidi, M. Mourshed, Y. Rezgui, Factors for effective BIM governance, Journal of Building $\quad$ Engineering, $10, \quad 89-101 \quad$ (2017). https://doi.org/10.1016/j.jobe.2017.02.006

16. S. Pittard, P. Sell, BIM and quantity surveying. New York: Routledge (2016).

17. R. Tulenheimo. Challenges of implementing new technologies in the world of BIM Case study from construction engineering industry in Finland. Procedia Economics and Finance, 21(Henttinen 2012), 469-477 (2015).

https://doi.org/10.1016/S2212-5671(15)00201-4

18. A.H. Memon, I.A, Rahman, I. Memon, N.I.A. Azman, BIM in Malaysian construction industry: Status, advantages, barriers and strategies to enhance the implementation level. Research Journal of Applied Sciences, Engineering and Technology, 8(5), 606614 (2014). https://doi.org/10.19026/rjaset.8.1012

19. S. Rokooei, Building Information Modeling in Project Management: Necessities, Challenges and Outcomes. Procedia - Social and Behavioral Sciences, 210, 87-95 (2015). https://doi.org/10.1016/j.sbspro.2015.11.332

20. R. Eadie, M. Browne, H. Odeyinka, C. McKeown, S. McNiff, BIM implementation throughout the UK construction project lifecycle: An analysis. Automation in Construction, 36, 145-151 (2013).

21. D. Migilinkas, V. Popov, V. Juocevicius, L. Ustinovichius, The benefits, obstacles and problems of practical bim implementation. Procedia Engineering, 57, 767-774 ( 2013). https://doi.org/10.1016/j.proeng.2013.04.097

22. D. Cao, H. Li, G. Wang, T. Huang, Identifying and contextualising the motivations for BIM implementation in construction projectsAn empirical study in China. International Journal of Project Management, 35(4), 658-669 (2017). https://doi.org/10.1016/j.ijproman.2016.02.002

23. S. Azhar, Building Information Modeling (BIM): Trends, Benefits, Risks, and Challenges for the AEC Industry.Leadership and Management in Engineering, 11(3), 241-252 (2011) .http://dx.doi.org/10.1061/(ASCE)LM.1943-5630.0000127

24. Q. He, L. Luo, Y. Hu, A.P.C. Chan, Measuring the complexity of mega construction projects in China-A fuzzy analytic network process analysis. International Journal of Project Management, 33(3), 549-563 (2015). https://doi.org/10.1016/j.ijproman.2014.07.009

25. M. Latham, Constructing the Team: Joint Review of Procurement and Contractual Arrangements in the United Kingdom Construction Industry:Final Report. London, England: H.M. Stationery Office (1994).

26. AEC (UK) BIM Technology Protocol v2.1. Retrieved May 2, 2017, from https://aecuk.files.wordpress.com/2015/06/aecukbimtechnologyprotocol-v2-1-1201506022.pdf

27. B. Hardin, D. McCool, BIM and Construction Management: Proven tools, methods and workflow. Indianapolis: Wiley Publishing, IN. (2015)

28. A. Tomek, P. Matejka, The impact of BIM on risk management As an argument for its implementation in a construction company. Procedia Engineering, 85, 501-509 (2014). https://doi.org/10.1016/j.proeng.2014.10.577

29. A. Porwal, K.N. Hewage, Building Information Modeling (BIM) partnering 
framework for public construction projects. Automation in Construction, 31, 204-214 (2013). https://doi.org/10.1016/j.autcon.2012.12.004

30. C. Sun, Q. Man, Y. Wang, Study on BIM-based construction project cost and schedule risk early warning. Journal of Intelligent and Fuzzy Systems, 29(2), 469-477 (2015). https://doi.org/10.3233/IFS-141178

31. D. Mehran, Exploring the Adoption of BIM in the UAE Construction Industry for AEC Firms. Procedia Engineering, 145, 1110-1118 ( 2016). https://doi.org/10.1016/j.proeng.2016.04.144 